ISSN: 1858-4837; E-ISSN: 2598-019X

Volume 17, Nomor 1 (2022),

https://jurnal.uns.ac.id/region

DOI: 10.20961/region.v1711.34839

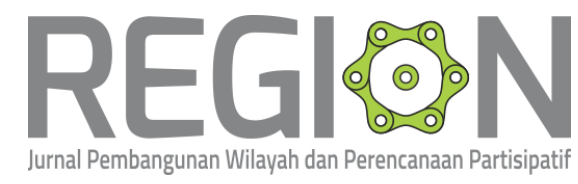

\title{
Hubungan perkembangan urban sprawl dan nilai tanah di barat Kota Surakarta
}

\author{
The Relation between Urban Sprawl Growth and Land Value in the West Side of \\ Surakarta
}

\author{
A Wibawa ${ }^{1}$, R P Utomo $^{1}$, dan N Miladan ${ }^{1}$ \\ ${ }^{1}$ Program Studi Perencanaan Wilayah dan Kota, Fakultas Teknik, Universitas Sebelas \\ Maret
}

Corresponding author's email: alvinwibawa@student.uns.ac.id

\begin{abstract}
Abstrak. Kota adalah tempat yang dinamis. Suatu kota akan selalu berkembang untuk memenuhi kebutuhan masyarakat yang berada di dalamnya. Kota yang semakin berkembang, maka akan menjadi magnet bagi penduduk di sekitarnya untuk mencari penghidupan yang layak. Hal ini yang dialami Kota Surakarta hingga menjadi magnet urbanisasi yang mengakibatkan fenomena urban sprawl dikarenakan perkembangannya merembet ke arah luar, salah satunya ke arah barat Kota Surakarta. Perkembangan yang tinggi menuntut kawasan barat Kota Surakarta untuk memenuhi kebutuhan ruang masyarakatnya. Tingginya permintaan akan ruang menjadikan pertumbuhan nilai tanah menjadi sangat pesat. Sedangkan, jumlah tanah yang berada di kawasan tersebut tidak dapat memenuhi permintaan. Pertumbuhan nilai tanah yang tiap tahun mengalami peningkatan yang tinggi membuat kekhawatiran tanah yang berada pada kawasan tersebut tidak terjangkau oleh masyarakat sehingga dibutuhkan pengetahuan mengenai hubungan antara perkembangan urban sprawl terhadap nilai tanah. Penelitian ini menggunakan pendekatan deduktif dengan menggunakan analisis korelasi pearson. Data yang digunakan peneliti dalam penelitian ini diperoleh melalui dokumen-dokumen institusional. Hasil analisis penelitian ini membuktikan bahwa komponen kepadatan memiliki nilai 0,357 yang berarti korelasi rendah terhadap nilai tanah, komponen jarak ke CBD memiliki nilai -0,481 dan variasi guna lahan memiliki nilai 0,424 yang berarti korelasi sedang dan komponen integrasi jaringan jalan utama tidak memiliki korelasi.
\end{abstract}

Kata Kunci: Nilai Tanah; Urban Sprawl; Urbanisasi

Received: October 04, 2019; Accepted: December 11, 2019; Available online: January 31, 2022

Copyright $\odot$ 2022, REGION: Jurnal Pembangunan Wilayah dan Perencanaan Partisipatif 


\begin{abstract}
A city is a dynamic place which will always develop to fulfill the needs of the society who live within its area. Along with its development, the city will become a magnet that attracts many people to find a better living. Such phenomenon happens in Surakarta City, in which it becomes an urbanization magnet that triggers urban sprawl due to its development spreading outwards, one of which was towards the west side of Surakarta. The high development requires the western region of Surakarta City to meet the public space needs. The high demand for space makes the land value growth rapidly, whereas the existing area cannot fulfill the demand. Each year, the land values grow rapidly that it is feared that the land is not affordable by the society. Therefore, knowledge about the relation between urban sprawl development and land values is needed. This research used a deductive approach assisted with pearson correlation analysis. The data used by the researcher were obtained from institutional documents. The results of this research prove that the density component has a value of 0.357 , which means a low correlation to the land value. In addition, the component of distance to CBD has a value of -0.481 and the land-use variation has a value of 0.424 which means that the correlation is moderate and the component of the main road network has no correlation.
\end{abstract}

Keywords: Land Value, Urban Sprawl, Urbanization

\title{
1. Pendahuluan
}

Kota dari waktu ke waktu akan mengalami perkembangan. Kota akan selalu tumbuh untuk memenuhi kebutuhan penduduk yang berada di dalamnya. Oleh sebab itu, Muta'ali [1] menyebut kota adalah tempat yang dinamis. Suatu kota yang mengalami perkembangan akan menjadikan kota tersebut menjadi magnet yang menarik untuk penduduk bertempat tinggal di kota. Hal ini ditujukan untuk mendapatkan kehidupan yang lebih layak [2]. Salah satu contohnya yang terjadi di Kota Surakarta. Pesatnya pembangunan fisik dan ekonomi di Kota Surakarta mendorong penduduk untuk mencari kehidupan yang lebih layak. Pada tahun 2016, menurut data yang dihimpun dari BPS menunjukkan bahwa jumlah penduduk Kota Surakarta berjumlah 514.171 jiwa serta pertumbuhan penduduknya berada pada angka 1,78\%/tahun [3]. Pesatnya pertambahan penduduk di Kota Surakarta mengakibatkan munculnya fenomena urbanisasi [4].

Pesatnya pertumbuhan pada suatu kota akan memberikan dampak, yaitu semakin padatnya suatu kota karena semakin banyak pula penduduk yang berdatangan. Selain dampak kependudukan, perkembangan kota akan memberikan dampak secara spasial bagi kehidupan kota, yaitu akan muncul tuntutan akan ruang dalam rangka untuk memenuhi kebutuhan penduduk [5]. Dampak yang ditimbulkan terkait dengan hal tersebut berupa semakin banyaknya penduduk yang datang, maka akan semakin tinggi pula kebutuhan lahan yang mengakibatkan terjadinya pertumbuhan kota yang melebihi batas administrasi dari kota atau yang sering dikenal dengan sebutan urban sprawl [6].

Menurut Hayden dalam Banai [7], urban sprawl merupakan sebuah proses perluasan pengembangan kawasan terbangun yang memiliki kepadatan bangunan maupun penduduk 
yang rendah, perkembangan yang menyebar/tidak saling terintegrasi, ketergantungan terhadap penggunaan kendaraan pribadi, serta perkembangan wilayah terbangun ini berada di kota pinggiran (urban fringe). Urban sprawl merupakan perkembangan permukiman di pinggiran kota inti (peri-urban) dengan kepadatan yang rendah (meliputi kepadatan penduduk dan bangunan), tersegregasi (tidak terintegrasi langsung dengan jalan utama), penggunaan lahan tunggal (single used) serta penduduknya merupakan komuter yang bekerja di kota inti [8-14]. Hal ini juga terjadi pada Kota Surakarta, keterbatasan lahan di dalam Kota Surakarta menyebabkan terjadinya perkembangan kota secara menjalar ke wilayah lain di sekitarnya.

Tingginya permintaan penduduk terhadap tanah akan mempengaruhi pergerakan harga tanah semakin tinggi $[15,16]$. Keterbatasan luasan tanah yang tidak sebanding dengan peningkatan kebutuhan akan tanah mengakibatkan harga tanah mengalami kenaikan tiap tahunnya dikarenakan tidak tercapainya keseimbangan antara permintaan dan penawaran. Hanifati [17] menjelaskan suatu nilai lahan dapat dinilai melalui nilai ekonomi atau tingkat produktivitas lahan tersebut sehingga dapat disimpulkan bahwa semakin produktif suatu suatu lahan yang dapat dilihat dari kompleksitas penggunaan lahan maka akan mengakibatkan meningkatnya nilai lahan. Selain itu, suatu kawasan memiliki nilai tanah lebih tinggi jika memiliki keunggulan tersendiri, salah satunya adalah integrasi atau keterjangkauan antara permukiman dengan jaringan jalan utama. Suatu kawasan yang terintegrasi pada suatu jaringan jalan utama akan meningkatkan nilai suatu kawasan tersebut [18]. Suatu kawasan yang mana kebutuhankebutuhan masyarakatnya sudah terjangkau secara jarak akan menjadi daya tarik tersendiri untuk ditinggali sehingga permintaan pada kawasan tersebut akan meningkat. Hal tersebut yang mendorong naiknya nilai tanah pada kawasan tersebut [18].

Pertumbuhan penduduk pada bagian barat Kota Surakarta cukup pesat karena adanya aksesibilitas yang baik serta merupakan jalur untuk menuju ke Bandara Adi Soemarmo. Perkembangan kawasan bagian barat Kota Surakarta ini juga didukung oleh peningkatan aktivitas ekonomi, sosial, dan budaya, sehingga terjadi perluasan area terbangun yang cukup tinggi. Perkembangan fisik kawasan ini selanjutnya mendorong terjadinya peningkatan nilai tanah. Oleh karena itu, penelitian ini bertujuan untuk mengetahui hubungan antara perkembangan urban sprawl terhadap nilai tanah di barat Kota Surakarta.

\section{Metode}

Penelitian ini memiliki tujuan untuk mengetahui hubungan perkembangan urban sprawl terhadap nilai tanah di barat Kota Surakarta. Kawasan penelitian yang dipilih oleh peneliti, yaitu sampel perumahan yang berada di 23 kelurahan di Kecamatan Kartasura dan Kecamatan Colomadu. Jenis penelitian yang digunakan peneliti adalah penelitian kuantitatif. Terdapat 2 jenis variabel pada penelitian ini, yaitu variabel mengenai komponen-komponen pembentuk urban sprawl dan nilai tanah yang berada di barat Kota Surakarta, yaitu nilai tanah tiap kelurahan di Kelurahan Colomadu dan Kelurahan Kartasura. Penjabaran variabel-variabel tersebut dapat dilihat pada Tabel 1. 
Tabel 1. Variabel penelitian.

\begin{tabular}{|c|c|c|c|}
\hline Variabel & Sub Variabel & Definisi Operasional & Sumber data \\
\hline \multirow{5}{*}{$\begin{array}{l}\text { Tingkat } \\
\text { Urban } \\
\text { Sprawl }\end{array}$} & $\begin{array}{l}\text { Kepadatan } \\
\text { Penduduk }\end{array}$ & $\begin{array}{l}\text { Jumlah penduduk pada suatu wilayah } \\
\text { dibandingkan dengan luas lahan } \\
\text { terbangun (jiwa/ha) }\end{array}$ & $\begin{array}{l}\text { Kecamatan Colomadu dan } \\
\text { Kartasura Dalam Angka } 2018\end{array}$ \\
\hline & $\begin{array}{l}\text { Kepadatan } \\
\text { Bangunan }\end{array}$ & $\begin{array}{l}\text { Jumlah bangunan pada suatu wilayah } \\
\text { dibandingkan dengan luas lahan } \\
\text { terbangun (bangunan/ha) }\end{array}$ & $\begin{array}{l}\text { Bappeda Kabupaten } \\
\text { Karanganyar dan Sukoharjo } \\
\text { (2019) }\end{array}$ \\
\hline & $\begin{array}{l}\text { Pembangunan } \\
\text { Terkoneksi } \\
\text { Jalan }\end{array}$ & $\begin{array}{l}\text { Jumlah bangunan terkoneksi jaringan } \\
\text { jalan dibandingkan jumlah seluruh } \\
\text { bangunan }\end{array}$ & - \\
\hline & $\begin{array}{l}\text { Jarak Menuju } \\
\text { Kota Inti }\end{array}$ & $\begin{array}{l}\text { Jarak antara kelurahan-kelurahan di } \\
\text { kawasan penelitian terhadap kota inti } \\
(\mathrm{Km})\end{array}$ & - \\
\hline & $\begin{array}{l}\text { Guna Lahan } \\
\text { Campuran }\end{array}$ & $\begin{array}{l}\text { Persentase luasan penggunaan lahan } \\
\text { dibandingkan luas wilayah penelitian } \\
\text { (\%) }\end{array}$ & $\begin{array}{l}\text { RTRW Kabupaten } \\
\text { Karanganyar 2013-2032 } \\
\text { RTRW Kabupaten Sukoharjo } \\
\text { 2011-2031 }\end{array}$ \\
\hline \multicolumn{2}{|c|}{ Nilai Tanah } & $\begin{array}{l}\text { Besaran nilai ekonomis pada suatu } \\
\text { tanah (Rp) }\end{array}$ & $\begin{array}{l}\text { Zona Nilai Tanah Badan } \\
\text { Pertanahan Nasional }\end{array}$ \\
\hline
\end{tabular}

Metode pengumpulan data yang peneliti gunakan adalah metode pengumpulan data sekunder. Pengumpulan data sekunder meliputi dalam mencari nilai kepadatan, nilai network analysis, nilai highway strip, penggunaan lahan dan nilai tanah pada Kecamatan Colomadu dan Kecamatan Kartasura melalui Organisasi Perangkat Daerah (OPD) setempat. Teknik analisis yang digunakan peneliti adalah analisis korelasi pearson, yaitu analisis untuk mencari korelasi antara 2 variabel yang memiliki skala interval atau rasio [19]. Sebelum data-data diinput ke aplikasi SPSS 25, peneliti melakukan analisis deskriptif terlebih dahulu pada variabel tingkat urban sprawl sehingga mendapatkan nilai komponen-komponen urban sprawl di kawasan penelitian. Maka setelah dilakukan analisis deskriptif pada variabel tingkat urban sprawl, dilakukan analisis korelasi pearson antara variabel tingkat urban sprawl dan variabel nilai tanah

\section{Hasil penelitian dan pembahasan}

\subsection{Perkembangan perumahan di barat Kota Surakarta}

Kecamatan Colomadu dan Kecamatan Kartasura pada perkembangan fisik terbangun khususnya sektor perumahan dapat terbilang cukup pesat. Hal ini dapat dilihat dalam kurun waktu tahun 2002 hingga tahun 2017 mengalami konversi lahan terbangun yang cukup pesat. Berdasarkan metode Normalized Difference Built-up Index (NDBI) didapatkan pemetaan lahan terbangun dan non terbangun pada kawasan penelitian yang dapat dilihat pada Gambar 1. 


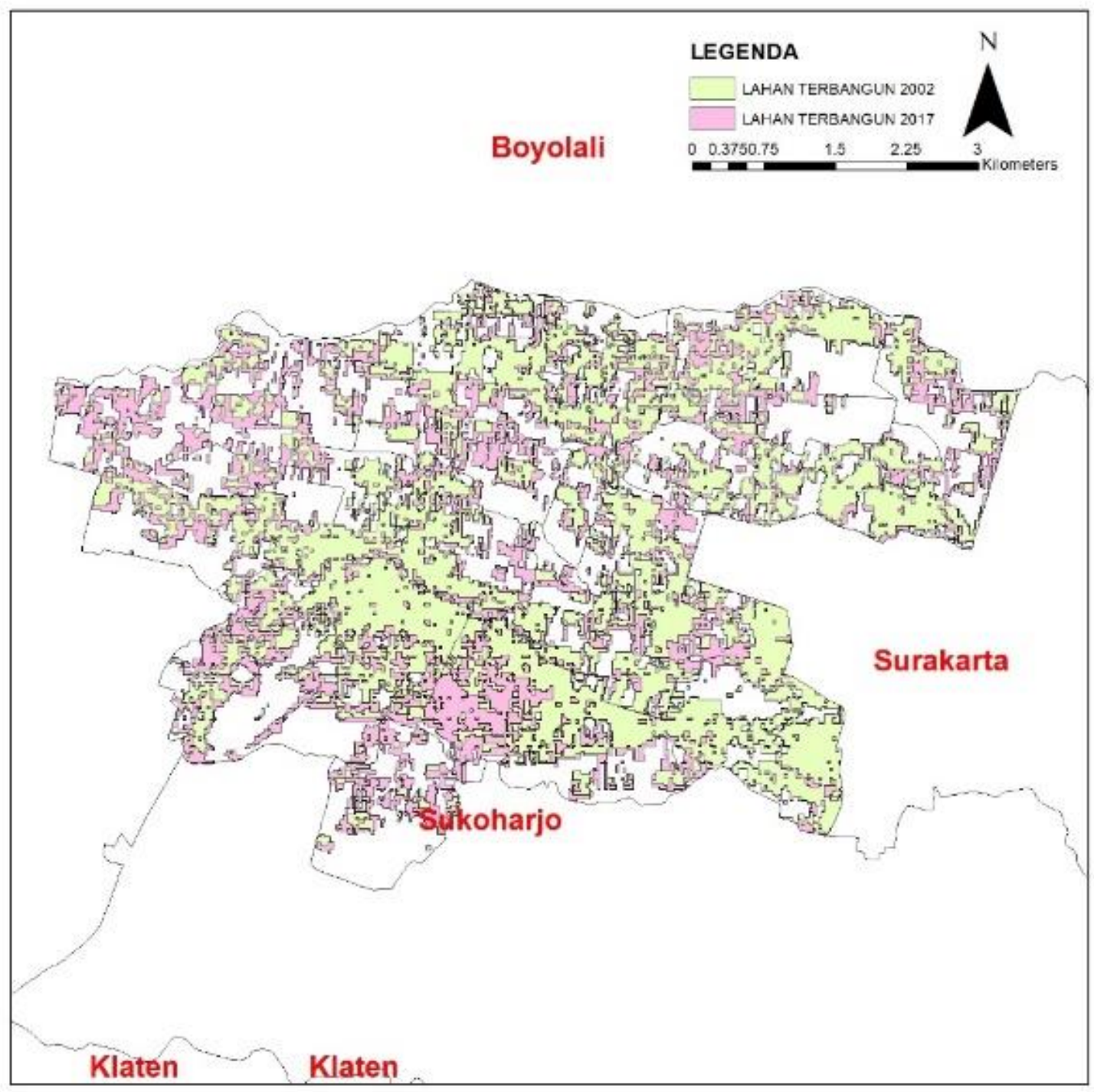

Gambar 1. Peta lahan terbangun tahun 2002 dan tahun 2017.

\subsection{Tingkat kepadatan yang rendah}

Setelah dilakukan analisis mengenai kepadatan yang mengacu terhadap SNI 03-1733-2004 [20] mengenai Tata Cara Perencanaan Lingkungan Perumahan di Perkotaan, hanya didapati 1 kelurahan yang tergolong berkepadatan penduduk sedang, yaitu Kelurahan Kartasura yang memiliki kepadatan penduduk sebesar 157,32 jiwa/Ha sedangkan kelurahan lain merupakan kelurahan yang memiliki kepadatan rendah ( $<150$ jiwa/Ha). Sedangkan, jika dilihat dari persentase lahan terbangun menunjukkan persentase lahan yang terbangun pada tiap kelurahan masih dibawah dari $50 \%$. Namun peneliti menggunakan pengklasifikasian dengan pembagian kelas nilai kepadatan menjadi 3 kategori kepadatan, yaitu kepadatan rendah, sedang, dan tinggi. Semakin rendah nilai kepadatan pada suatu kawasan maka akan semakin tinggi pula nilai urban sprawl pada kawasan tersebut. 
Jika melihat tingkat kepadatan yang masih sangat rendah di kawasan penelitian, hal ini disebabkan karena pertumbuhan kawasan terbangun khususnya perumahan pada tiap kelurahan tumbuh secara sporadic atau dapat dikatakan pertumbuhan yang cepat dan tanpa arah. Perumahan-perumahan yang ada di kawasan penelitian tidak terintegrasi satu sama lainnya. Maka dengan munculnya perumahan-perumahan yang berpencar pada tiap kelurahan mengakibatkan kepadatan tiap kelurahan di kawasan penelitian menjadi rendah. Berikut merupakan peta kepadatan di kawasan penelitian yang dapat dilihat pada Gambar 2.

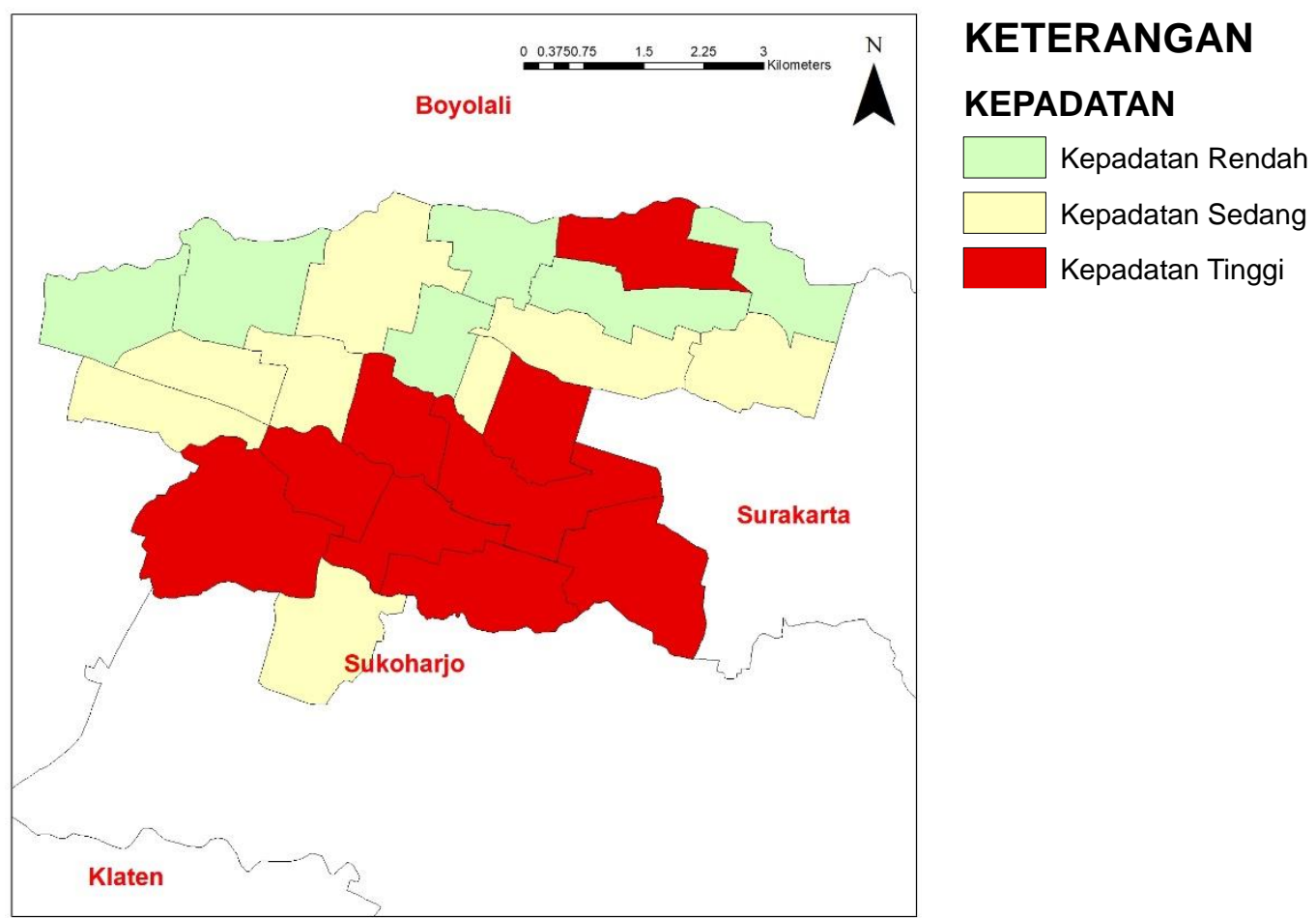

Gambar 2. Peta kepadatan kawasan penelitian.

\subsection{Perumahan yang tidak terintegrasi oleh jaringan jalan utama}

Bangunan yang tidak terkoneksi jalan merupakan salah satu pertanda bahwa kawasan terindikasi mengalami urban sprawl. Kawasan yang kompak tiap bangunan yang berdiri pada suatu kawasan saling terkoneksi oleh jaringan jalan utama. Maka dalam menentukan tingkat keterjangkauan suatu bangunan pada kawasan digunakan Indeks Highway Strip (IHS) dengan menilai bangunan yang berada pada jangkauan $100 \mathrm{~m}$ jalan arteri dan jalan kolektor dibanding dengan seluruh bangunan yang berdiri pada kawasan tersebut lalu didapatkan indeks tersebut [21].

Pada kasus kelurahan-kelurahan yang berada di barat Kota Surakarta masih banyak bangunan yang belum terkoneksi oleh jaringan jalan arteri dan jaringan jalan kolektor. Setelah dilakukan perhitungan index highway strip, maka didapati bahwa kelurahan yang memiliki IHS terbesar adalah Kelurahan Ngadirejo dan Kelurahan Kartasura dengan nilai IHS sebesar 0.97, sedangkan kelurahan yang memiliki IHS terkecil adalah Kelurahan Tohudan dengan nilai IHS sebesar 0.02. 
Oleh karena itu Kelurahan Tohudan adalah kelurahan yang memiliki nilai urban sprawl terbesar.

\subsection{Jarak kelurahan di Kecamatan Colomadu dan Kartasura ke Kota Surakarta yang beragam} Menurut Galster et al dalam Bhatta, B [12] dalam menilai tingkat urban sprawl pada kawasan penelitian, jarak permukiman terjauh tiap kelurahan sangat mempengaruhi tingkatan urban sprawl. Hal ini dikarenakan perkembangan fisik suatu kawasan dapat merupakan efek tarikan dari kawasan lain di sekitarnya (growth pole). Maka semakin dekat suatu kawasan dengan magnet tumbuhnya akan memberikan efek perkembangan yang lebih besar dibandingkan dengan kawasan yang jarak yang jauh pada magnet perkembangannya.

Pada kelurahan-kelurahan di barat Kota Surakarta menunjukkan bahwa jarak tiap perumahan ke Kota Surakarta memiliki nilai yang beragam. Hal tersebut didapati bahwa kelurahan yang memiliki jarak terjauh menuju Kota Surakarta adalah Kelurahan Kertonatan yang memiliki jarak sebesar $8,86 \mathrm{~km}$ dan kelurahan yang memiliki jarak terdekat dengan Kota Surakarta adalah Kelurahan Gonilan. Oleh karena itu, setelah dilakukan analisis jarak permukiman terjauh menuju Kota Surakarta Kelurahan Kertonatan memiliki nilai urban sprawl yang tertinggi.

\subsection{Guna lahan yang kurang bervariasi}

Guna lahan campuran merupakan variabel dalam menentukan tingkat urban sprawl pada suatu kawasan. Adanya integrasi guna lahan dibutuhkan untuk mendekatkan jarak antara masyarakat dengan aktivitas-aktivitas yang dibutuhkan. Maka semakin tidak terintegrasinya kawasan perumahan dengan guna lahan yang dibutuhkan masyarakat (single use) berakibat pada tingkat urban sprawl pada kawasan penelitian akan semakin tinggi, sebaliknya semakin terintegrasinya kawasan perumahan dengan guna lahan yang dibutuhkan masyarakat (mixed use) maka semakin kecil pula tingkat urban sprawl atau sering disebut dengan urban compact [22].

Pada kasus kelurahan-kelurahan di kawasan penelitian penggunaan lahan cenderung tidak beragam dikarenakan mayoritas penggunaan lahan pada kawasan penelitian merupakan kawasan perumahan serta tidak terintegrasi secara optimal dengan jenis penggunaan lahan lainnya (lihat Gambar 3). Hal tersebut dikarenakan perumahan-perumahan cenderung mengelompok pada suatu kawasan yang membentuk kantong-kantong, sedangkan masyarakat yang tinggal di dalamnya cenderung berkegiatan di luar kawasan tersebut. Jika dilihat dari besaran jenis penggunaan lahan Kelurahan Pabelan merupakan kelurahan yang paling kompak di kawasan penelitian dikarenakan tingkat keberagaman penggunaan lahan di Kelurahan Pabelan merupakan paling tinggi dibandingkan dengan kelurahan-kelurahan lain, sedangkan kelurahan dengan tingkat keberagaman penggunaan lahan terkecil berada pada Kelurahan Gajahan. Oleh karena itu, nilai urban sprawl pada Kelurahan Gajahan merupakan yang tertinggi dibandingkan dengan kelurahan lainnya. 

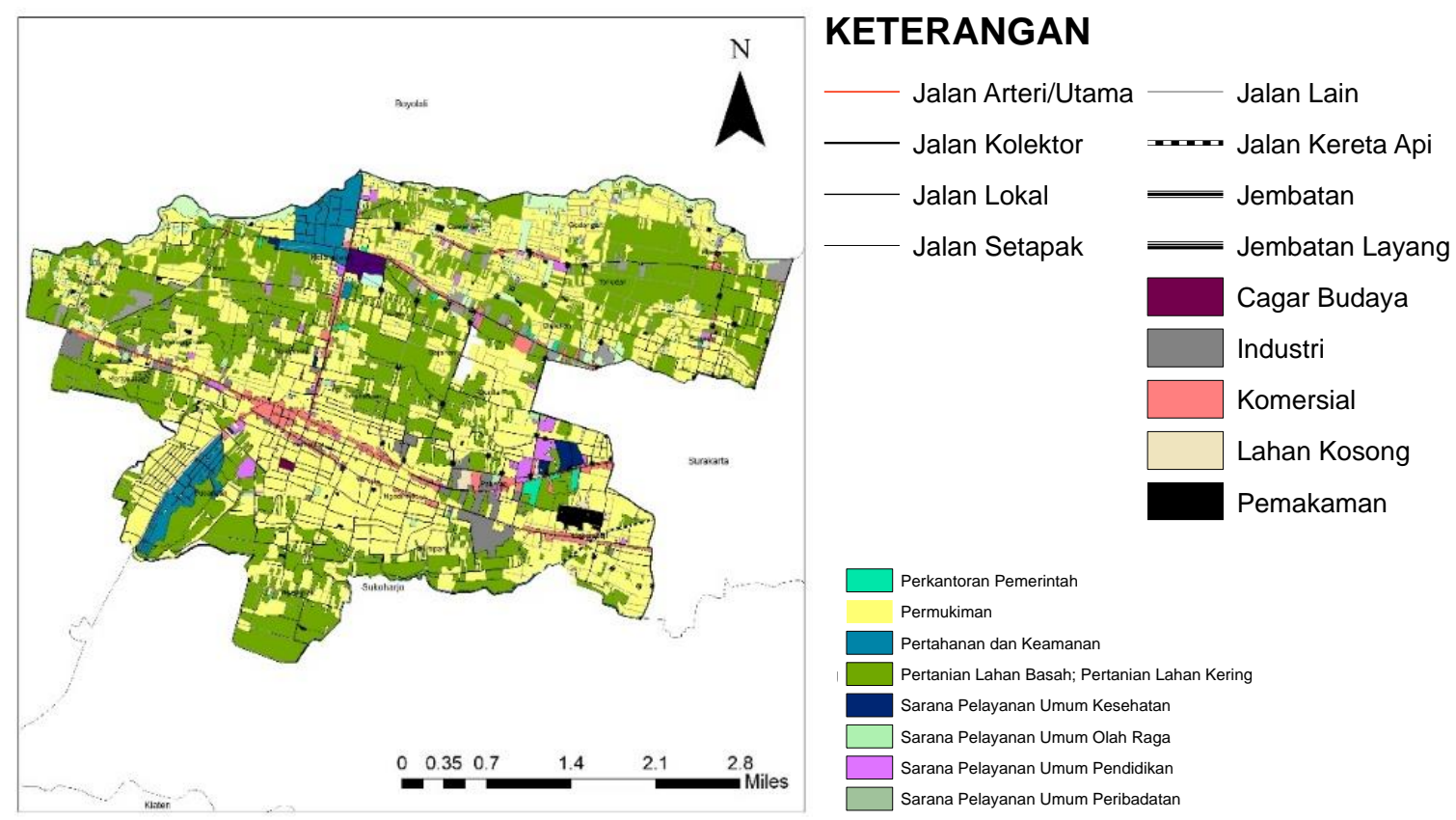

Gambar 3. Peta guna lahan kawasan penelitian.

\subsection{Nilai tanah di Kecamatan Colomadu dan Kecamatan Kartasura}

Nilai tanah merupakan nilai ekonomis pada suatu wilayah. Suatu kawasan yang memiliki nilai ekonomis yang lebih rendah dibandingkan tempat lain akan mendorong masyarakat untuk bertempat tinggal pada suatu wilayah tertentu. Hal ini memiliki kesinambungan dengan harga lahan di kota inti yang lebih tinggi dibandingkan dengan wilayah pinggiran kota sehingga mendorong masyarakat untuk bertempat tinggal di wilayah pinggiran kota dikarenakan harga lahan yang lebih murah. Oleh karena itu, semakin murahnya nilai tanah di wilayah pinggiran kota maka akan semakin kuat pula dorongan masyarakat untuk bertempat tinggal di pinggiran kota [12]. Berikut merupakan nilai-nilai tanah di kawasan penelitian (lihat Tabel 2).

Tabel 2. Nilai tanah kawasan penelitian [23].

\begin{tabular}{cccc}
\hline Kelurahan & Nilai Tanah $\left(\mathbf{R p} / \mathbf{m}^{\mathbf{2}}\right)$ & Kelurahan & Nilai Tanah $\left(\mathbf{R p} / \mathbf{m}^{\mathbf{2}}\right)$ \\
\hline Baturan & 212,020 & Wirogunan & 461,866 \\
Blulukan & 387,098 & Kertonatan & 423,378 \\
Bolon & 179,282 & Kartasura & $1,008,490$ \\
Gajahan & 547,752 & Ngemplak & 192,445 \\
Gawanan & 455,227 & Ngabeyan & 461,866 \\
Gedongan & 277,291 & Ngadirejo & $1,008,490$ \\
Klodran & $1,089,285$ & Singopuran & 481,112 \\
Malangjiwan & 367,081 & Pabelan & $1,080,525$ \\
Ngasem & 179,282 & Makamhaji & $1,040,849$ \\
Paulan & 410,816 & Gonilan & $1,080,525$ \\
Tohudan & 855,578 & Gumpang & 336,780 \\
Pucangan & 230,935 & Kota Surakarta & $1,126,185$ \\
\hline
\end{tabular}

Received: October 04, 2019; Accepted: December 11, 2019; Available online: January 31, 2022 
Pada kasus di Kecamatan Colomadu dan Kecamatan Kartasura, nilai tanah kawasan tersebut memiliki nilai yang jauh lebih rendah dibandingkan dengan Kota Surakarta dengan nilai terendah ada pada Kelurahan Bolon dan Kelurahan Ngasem, yaitu Rp 179.282 sedangkan di Kota Surakarta nilai terendahnya, yaitu ada pada angka Rp 1.126.185. Namun pada variabel ini tidak termasuk variabel yang berpengaruh secara signifikan pada perkembangan urban sprawl. Namun nilai tanah akan menjadi pertimbangan bagi para penduduk/developer untuk bertempat tinggal/membangun perumahan. Hal ini dikarenakan, jika nilai tanah pada periurban lebih rendah dibandingkan kota inti maka akan menjadi daya tarik bagi penduduk/developer untuk memilih kawasan tersebut untuk ditinggali atau dikembangkan.

\subsection{Analisis hubungan komponen urban sprawl terhadap nilai tanah}

3.7.1. Analisis korelasi kepadatan terhadap nilai tanah. Berdasarkan prinsip harga keseimbangan dalam ilmu ekonomi, yaitu suatu benda yang memiliki permintaan yang melebihi dengan jumlah barang yang ditawarkan akan membuat nilai suatu barang tersebut menjadi naik atau lebih tinggi [24]. Layaknya barang yang diperjual belikan, nilai tanah akan selalu berkembang dikarenakan fenomena urbanisasi yang berkembang secara pesat akan mengakibatkan kebutuhan ruang semakin tinggi pula [18]. Oleh karena itu, dengan meningkatnya kebutuhan suatu ruang mengakibatkan permintaan terhadap ruang atau tanah akan semakin tinggi pula. Maka dapat disimpulkan bahwa hubungan antara komponen kepadatan pada urban sprawl dengan nilai tanah mempunyai hubungan positif yang artinya semakin padat suatu kawasan maka mengakibatkan nilai tanah tersebut menjadi lebih tinggi. Hal ini terjadi pada kawasan penelitian, yaitu kelurahan-kelurahan yang berada di Kecamatan Colomadu dan Kecamatan Kartasura. Kawasan-kawasan tersebut merupakan kawasan yang padat dan cenderung memiliki nilai tanah yang lebih tinggi dari kawasan sekitarnya seperti di beberapa kelurahan di Kecamatan Kartasura, yaitu Kelurahan Pabelan, Kelurahan Kartasura dan Kelurahan Makamhaji. Kelurahan tersebut memiliki kepadatan tinggi dengan nilai tanah $>$ Rp 1.000.000/m2. Berdasarkan hasil analisis korelasi antara kepadatan dan nilai tanah menunjukkan nilai korelasi sebesar 0,357 yang berarti memiliki korelasi tetapi tergolong kategori rendah [25]. Maka dengan tingkat kepercayaan sebesar 90\%, korelasi antara kepadatan dan nilai tanah memiliki kekuatan sebesar 0,094 atau lebih kecil dari 0,1 yang berarti hubungan antara komponen kepadatan pada urban spraw/ terhadap nilai tanah adalah signifikan. Berikut merupakan diagram sebar korelasi kepadatan dan nilai tanah yang dapat dilihat pada Gambar 4. 


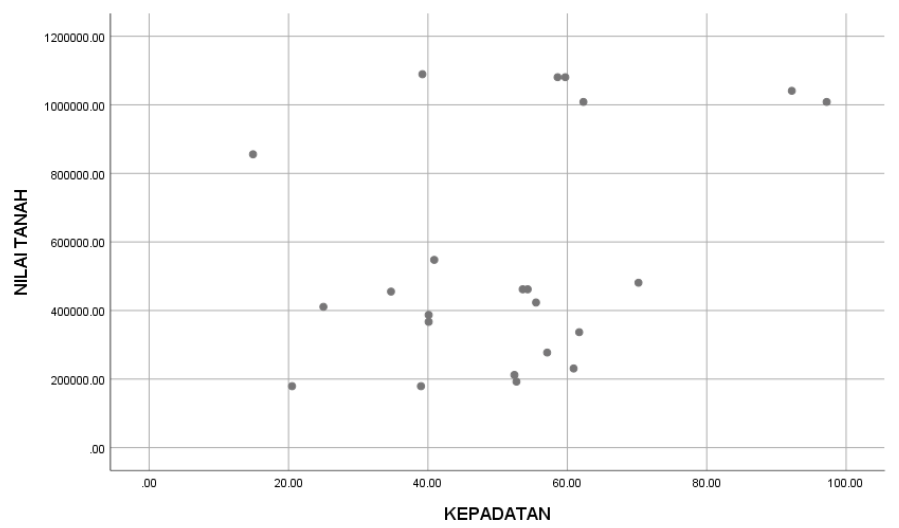

Gambar 4. Diagram sebar korelasi kepadatan dan nilai tanah.

3.7.2. Analisis korelasi integrasi jaringan jalan utama terhadap nilai tanah. Kemudahan penduduk untuk menjangkau jaringan jalan akan memberikan nilai tambah pada suatu kawasan dikarenakan hal ini memudahkan masyarakat beraktivitas untuk memenuhi kebutuhannya, seperti bekerja, sekolah dll [26]. Permukiman yang terintegrasi dengan jaringan jalan utama menurut Betts [27] akan mempengaruhi nilai suatu tanah atau kawasan karena adanya kemudahan mengakses fasilitas-fasilitas umum dan kebutuhan lainnya yang mana selalu menjadi penawaran properti kepada konsumen. Kawasan yang memiliki integrasi yang baik terhadap jaringan jalan utama dipandang oleh developer atau penghuni permukiman tersebut memiliki nilai lebih. Maka dapat disimpulkan bahwa hubungan antara integrasi jaringan jalan utama terhadap nilai tanah adalah bernilai positif yang berarti semakin tinggi integrasi suatu kawasan terhadap jaringan jalan utama akan mengakibatkan kenaikan pada nilai tanah tersebut. Namun yang terjadi di Kecamatan Colomadu dan Kecamatan Kartasura adalah perumahan-perumahan baru tersebar secara acak dan tidak beraturan jauh serta jauh dari jaringan jalan utama. Hal ini dikarenakan para developer memiliki preferensi tersendiri dan cenderung memilih tanah untuk dibangun dengan harga yang murah. Namun tren harga tanah yang berada di Kecamatan Colomadu dan Kecamatan Kartasura cenderung tidak tergantung dengan jangkauan jaringan jalan utama. Hasil analisis korelasi antara integrasi jaringan jalan utama dan nilai tanah menunjukkan nilai korelasi sebesar 0,025 yang memiliki arti tidak memiliki korelasi antara jaringan jalan utama terhadap nilai tanah [25]. Maka dengan tingkat kepercayaan sebesar 90\%, korelasi antara integrasi jaringan jalan utama terhadap nilai tanah memiliki kekuatan sebesar 0,908 atau lebih besar dari 0,1 yang berarti hubungan antara integrasi jaringan jalan utama terhadap nilai tanah adalah tidak signifikan. Berikut merupakan diagram sebar korelasi integrasi jaringan jalan utama dan nilai tanah yang dapat dilihat pada Gambar 5. 


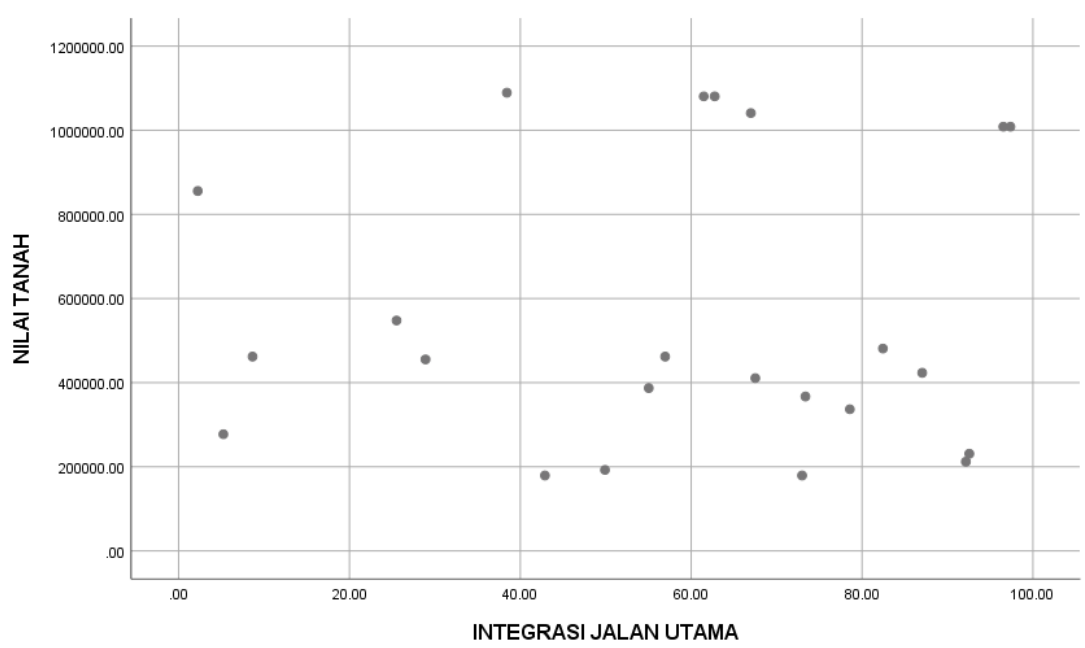

Gambar 5. Diagram sebar korelasi integrasi jaringan jalan utama dan nilai tanah.

3.7.3. Analisis korelasi jarak menuju CBD terhadap nilai tanah. Suatu permukiman memiliki nilai tinggi apabila jarak antara pusat kegiatan dengan permukiman lebih dekat. Hal ini dikarenakan dengan lebih dekatnya suatu permukiman dengan pusat kegiatan akan membuat usaha para masyarakat untuk menuju lokasi kegiatannya lebih kecil. Menurut Hermit [28] menjelaskan jarak suatu kawasan menuju pusat kegiatannya akan mempengaruhi pergerakan nilai tanah, seperti halnya jika suatu kawasan merupakan persawahan akan memiliki nilai tanah yang lebih rendah dibandingkan kawasan yang memiliki jarak yang lebih pendek untuk menuju pusat kegiatannya. Oleh karena itu, dapat disimpulkan bahwa hubungan korelasi antara jarak menuju pusat kegiatan terhadap nilai tanah adalah positif yang berarti semakin dekatnya suatu kawasan terhadap pusat kegiatan akan mengakibatkan nilai tanah menjadi naik. Namun yang terjadi di Kecamatan Colomadu dan Kecamatan Kartasura adalah sebaliknya, yaitu suatu kawasan yang memiliki jarak yang lebih dekat dengan pusat kegiatan memiliki nilai tanah yang lebih rendah. Hal ini dikarenakan masyarakat yang tinggal di Kecamatan Colomadu dan Kecamatan Kartasura memilih kenyamanan bermukim, yaitu suasana yang lebih tenang. Hal ini didasari oleh keberadaan Kecamatan Colomadu dan Kecamatan Kartasura yang berada di perbatasan dan dilalui oleh jaringan jalan arteri dan kolektor serta berdekatan dengan Pintu Tol Colomadu. Permukiman masyarakat cenderung menjorok lebih dalam dan tersebar. Hasil korelasi antara jarak menuju CBD terhadap nilai tanah menunjukkan nilai korelasi sebesar 0,481 yang memiliki arti korelasi terbalik [25]. Maka dengan tingkat kepercayaan sebesar $90 \%$, korelasi antara jarak ke CBD terhadap nilai tanah memiliki kekuatan sebesar 0,02 atau lebih kecil dari 0,1 yang berarti hubungan antara jarak ke CBD terhadap nilai tanah adalah signifikan. Berikut merupakan diagram sebar korelasi jarak ke CBD dengan nilai tanah yang dapat dilihat pada Gambar 6. 


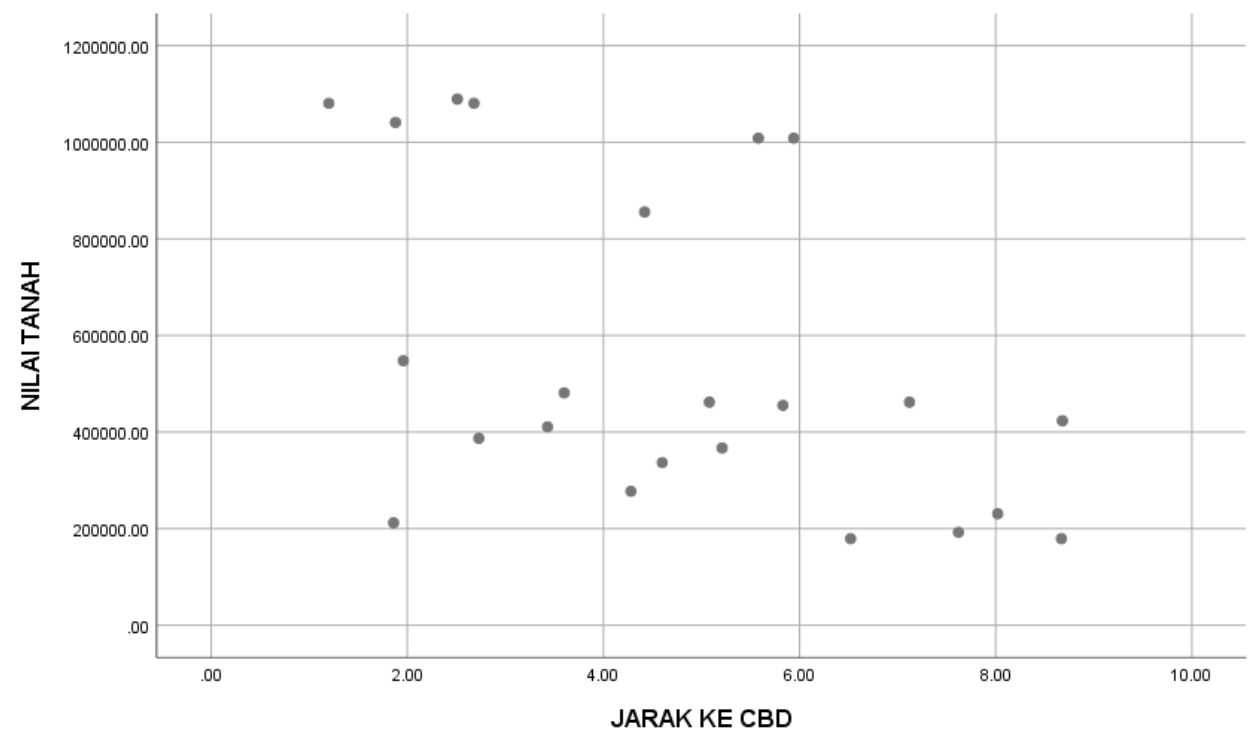

Gambar 6. Diagram sebar korelasi jarak ke CBD dan nilai tanah.

3.7.4. Analisis korelasi keragaman guna lahan terhadap nilai tanah. Produktivitas suatu lahan akan mempengaruhi nilai suatu tanah. Kawasan yang di atasnya memiliki kegiatan yang kompleks atau memiliki guna lahan yang lebih kompleks dianggap lebih produktif sehingga dengan kompleksitas guna lahan suatu kawasan akan mempengaruhi perkembangan nilai tanah [29]. Kawasan perkotaan yang kompak (compact city) memiliki kegiatan yang kompleks sehingga memiliki produktivitas yang tinggi. Sedangkan kawasan perkotaan yang tidak kompak (urban sprawl), cenderung memiliki kegiatan yang sejenis, yaitu didominasi oleh permukiman. Hal ini mengakibatkan nilai produktivitas kawasan tersebut menjadi lebih rendah yang pada akhirnya mengakibatkan nilai tanah pada kawasan yang kompak menjadi tinggi sedangkan kawasan yang tidak kompak menjadi lebih rendah. Oleh karena itu, dapat disimpulkan bahwa hubungan korelasi antara keragaman guna lahan terhadap nilai tanah adalah positif yang berarti semakin kompleksnya kegiatan pada suatu kawasan akan mengakibatkan nilai tanah menjadi naik. Fenomena yang terjadi pada Kecamatan Colomadu dan Kecamatan Kartasura menunjukkan bahwa terjadi hubungan yang linier antara keragaman guna lahan terhadap nilai tanah, yaitu suatu kawasan yang memiliki guna lahan yang lebih beragam menjadikan nilai tanah pada kawasan tersebut menjadi lebih tinggi dibandingkan dengan kawasan yang memiliki guna lahan yang cenderung tunggal. Hal ini terjadi pada Kelurahan Klodran, Kelurahan Kartasura dan Kelurahan Pabelan. Guna lahan di kelurahan-kelurahan tersebut lebih kompleks dan memiliki nilai tanah yang relatif lebih tinggi dibandingkan dengan kelurahan-kelurahan lainnya yang guna lahannya tidak lebih kompleks. Hasil korelasi antara keragaman guna lahan terhadap nilai tanah menunjukkan nilai korelasi sebesar 0,424 yang memiliki arti korelasi yang cukup [25]. Maka dengan tingkat kepercayaan sebesar $90 \%$, korelasi antara keragaman guna lahan terhadap nilai tanah memiliki kekuatan sebesar 0,044 atau lebih kecil dari 0,1 yang berarti hubungan antara keragaman guna lahan terhadap nilai tanah adalah signifikan. Berikut merupakan diagram sebar korelasi keragaman guna lahan dan nilai tanah yang dapat dilihat pada Gambar 7. 


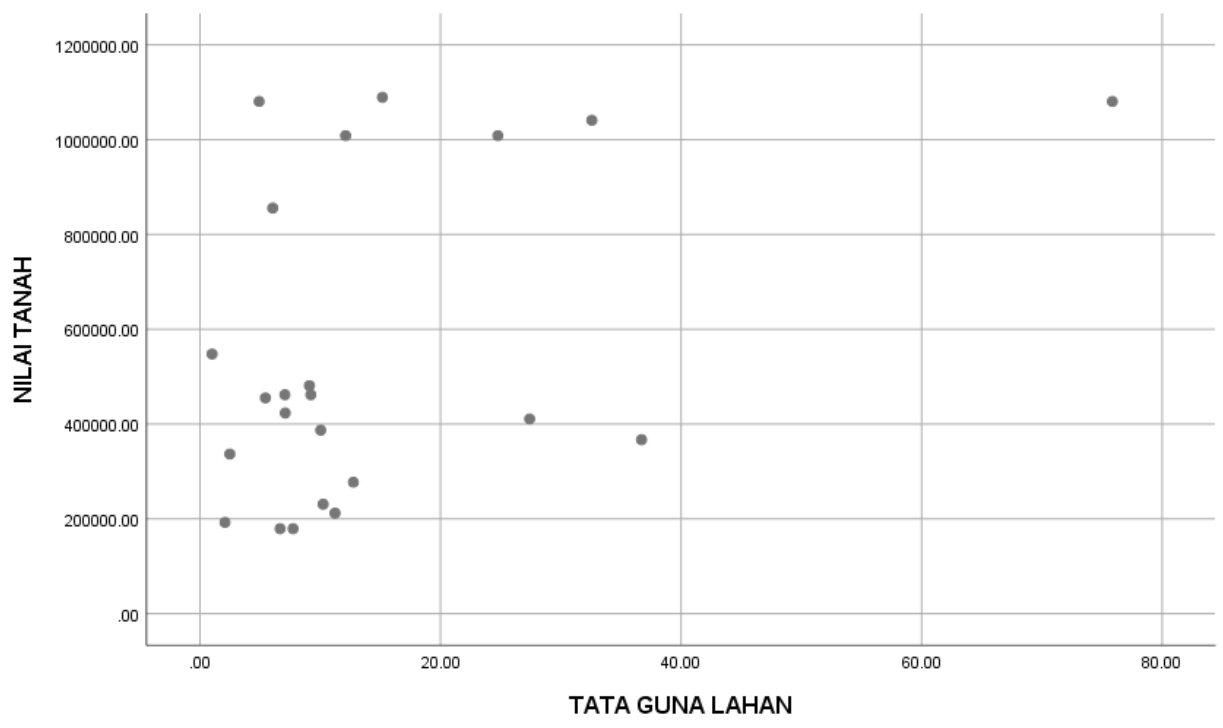

Gambar 7. Diagram sebar korelasi keragaman guna lahan dan nilai tanah.

\section{Kesimpulan}

Kecamatan Colomadu dan Kecamatan Kartasura merupakan kecamatan yang berbatasan langsung dan terkena dampak dari perkembangan Kota Surakarta. Peningkatan kebutuhan tempat tinggal yang sudah tidak mampu dipenuhi oleh Kota Surakarta mendorong masyarakat untuk menuju ke kawasan peri-urban Kota Surakarta, salah satunya ke arah barat Kota Surakarta, yaitu Kecamatan Colomadu dan Kecamatan Kartasura. Berdasarkan penelitian yang dilakukan peneliti untuk mengetahui hubungan antara perkembangan komponen pembentuk urban sprawl terhadap nilai tanah pada Kecamatan Colomadu dan Kecamatan Kartasura memiliki hasil bahwa kepadatan memiliki tingkat korelasi yang rendah. Peningkatan jumlah penduduk dan peningkatan pembangunan secara signifikan mengakibatkan kenaikan nilai tanah pada kawasan tersebut. Berikutnya, integrasi antara permukiman dan jaringan jalan utama tidak memiliki korelasi secara signifikan dikarenakan masyarakat pada kawasan tersebut memiliki preferensi tempat tinggal secara acak asal memiliki nilai tanah yang lebih murah dibandingkan kota inti. Sedangkan pada sub variabel jarak menuju CBD menunjukkan tingkat korelasi yang cukup signifikan namun memiliki arah yang terbalik, yaitu semakin dekatnya dari CBD justru memiliki nilai tanah yang lebih rendah. Hal ini didasari oleh masyarakat yang lebih memilih tempat tinggal yang jauh lebih tenang dibandingkan dengan lokasi yang berdampingan dengan CBD yang dirasa lebih ramai. Pada sub variabel terakhir, yaitu keragaman guna lahan memiliki tingkat korelasi yang cukup signifikan. Hal ini didasari oleh semakin produktifnya suatu lahan akan mengakibatkan nilai jual suatu properti menjadi lebih tinggi.

\section{Ucapan Terimakasih}

Pada proses pembuatan artikel ini banyak pihak yang membantu penulis sehingga dapat menyelesaikan artikel ini, untuk itu penulis ingin mengucapkan terima kasih kepada Program Studi Perencanaan Kota dan Wilayah, Fakultas Teknik, Universitas Sebelas Maret yang telah memfasilitasi kegiatan penelitian ini dan instansi Pemerintah Kota Surakarta, Pemerintah 
Kabupaten Karanganyar dan Pemerintah Kabupaten Sukoharjo yang telah membantu memberikan informasi untuk kegiatan penelitian ini.

\section{Referensi}

[1] Muta'ali L. Kapita Selekta Pembangunan Wilayah. Yogyakarta: Badan Penerbit Fakultas Geografi (BPFG) Universitas Gadjah Mada; 2011.

[2] Harahap FR. DAMPAK URBANISASI BAGI PERKEMBANGAN KOTA DI INDONESIA. J Soc 2013;1:35-45.

[3] Badan Pusat Statistik Kota Surakarta. Kota Surakarta Dalam Angka 20172015.

[4] Abbas A. Diktat Untuk Kalangan Sendiri : Sosiologi Perkotaan. Padang: Jurusan Sosiologi Universitas Andalas; 2002.

[5] Yunus HS. Manajemen Kota : Perspektif Spasial. Yogyakarta: Pustaka Belajar; 2005.

[6] Yunus HS. Struktur Tata Ruang Kota. Yogyakarta: Pustaka Belajar; 2000.

[7] Banai R, DePriest T. Urban Sprawl: Definitions, Data, Methods of Measurement, and Environmental Consequences. J Sustain Educ 2014;7:1-15.

[8] Apriani V, Asnawi A. Tipologi Tingkat Urban Sprawl di Kota Semarang Bagian Selatan. Tek PWK (Perencanaan Wil Kota) 2015;4:405-16.

[9] Jain M, Dimri AP, Niyogi D. Urban sprawl patterns and processes in delhi from 1977 to 2014 based on remote sensing and spatial metrics approaches. Earth Interact 2016;20:1-29. https://doi.org/10.1175/EI-D-15-0040.1.

[10] Burchell RW, Anthony MB. Sprawl Cost, Economic Impacs of Unchecked Development. Washington DC: Island Press; 2005.

[11] Dumreicher H, Levine RS, Yanarella EJ. The Appropiate Scale of "Low Energy": Theory and Practice at The Westbahnhof. S. Koen S. Yannas (Eds.), Archit. City Environtment Proc. PLEA 2000, London: James \& James; 2000, p. 359-63.

[12] Bhatta B. Analysis of Urban Growth and Sprawl from Remote Sensing Data. Berlin: Springer; 2010.

[13] Febri T. Kemungkinan Penerapan Konsep Compact City di Kawasan Jabodetabek Studi Kasus : Rasuna Epicentrum. Universitas Indonesia, 2012.

[14] Mujiandari R. Perkembangan Urban Sprawl Kota Semarang pada Wilayah Kabupaten Demak Tahun 2001-2012. J Wil Dan Lingkung 2014;2:129-42. https://doi.org/10.14710/jwl.2.2.129-142.

[15] Kivell P. Land and The City: Patterns and Processes of Urban Change. New York: Roudledge; 1993.

[16] Oktora R. Persepsi masyarakat terhadap pembangunan jalan lingkar utara kota solok provinsi sumatera barat tesis. Univesitas Diponegoro, 2011.

[17] Hanifati SF. Analisis Nilai Lahan Di Kecamatan Mantrijeron Kota Yogyakarta Dengan Aplikasi Penginderaan Jauh Dan Sistem Informasi Geografis. Universitas Muhammadiyah Surakarta, 2016.

[18] Fahirah F, Basong A, Tagala HH. Identifikasi Faktor Yang Mempengaruhi Nilai Jual Lahan dan Kabngunan Pada Perumahan Tipe Sederhana. J SMARTek 2010;8:251-69.

[19] Sugiyono. Metode Penelitian Pendidikan Pendekatan Kuantitatif, Kualitatif, dan R\&D. Bandung: Alfabeta; 2014. 
[20] Badan Standarisasi Nasional. SNI 03-1733-2004 tentang Tata Cara Perencanaan Lingkungan Perumahan di Perkotaan 2004.

[21] Hasse J, Lathrop RG. A housing-unit-level approach to characterizing residential sprawl. Photogramm Eng Remote Sensing 2003;69:1021-30. https://doi.org/10.14358/PERS.69.9.1021.

[22] Burton E. The compact city: just or just compact? A preliminary analysis. Urban Stud 2000;37:1969-2001. https://doi.org/10.1080/00420980050162184.

[23] Kementerian ATR/BPN. Peta Zona Nilai Tanah 2019. https://bhumi.atrbpn.go.id/ (accessed January 27, 2022).

[24] Sukirno. Mikro Ekonomi, Teori Pengantar. Jakarta: PT. Raja Grafindo Persada; 2005.

[25] Guilford JP. Fundamental Statistic in Psychology and Education. 3rd Ed. New York: McGraw-Hill Book Company, Inc; 1956.

[26] Rynjani GPR, Haryanto R. Kajian Harga Tanah Dan Penggunaan Lahan Di Kawasan Perdagangan Dan Jasa Kelurahan Lamper Kidul, Kota Semarang. Tek Perenc Wil Kota 2015;4:417-27.

[27] Betts RM, Ely SJ. Basic Real Estate Appraisal, 5th edition. New Jersey: Prentice Hall; 2001.

[28] Hermit H. Teknik Penaksiran Harga Tanah Perkotaan. Bandung: CV. Mandar Maju; 2009.

[29] Yunus HS. Metodologi Penelitian Wilayah Kontemporer. Yogyakarta: Pustaka Belajar; 2010. 